\title{
Evidence for transcript-specific epigenetic regulation of glucocorticoid-stimulated skeletal muscle $11 \beta$-hydroxysteroid dehydrogenase-1 activity in type 2 diabetes
}

Warrick J Inder ${ }^{1,2,3^{*}}$, Varuni R Obeyesekere ${ }^{1}$, Christina Jang ${ }^{1,4}$ and Richard Saffery ${ }^{5}$

\begin{abstract}
Background: The enzyme 11ß-hydroxysteroid dehydrogenase type 1 (11ßHSD1) converts inactive cortisone into active cortisol in insulin target tissues. In people with type 2 diabetes, skeletal muscle (SkM) 11ßHSD1 is upregulated by the potent glucocorticoid dexamethasone. The HSD11B1 gene has two promoters designated P1 and P2. CCAAT/enhancer-binding protein beta (C/EBP $\beta$ ) is known to regulate expression of $11 \beta H S D 1$ via the P2 promoter. In this study, we investigated the potential role of altered DNA methylation of the P1 and P2 promoters in the observed dexamethasone-induced upregulation of SkM $11 \beta$ HSD1 oxoreductase activity in human diabetic subjects. SkM biopsies from 15 people with type 2 diabetes were collected before and after treatment with oral dexamethasone $4 \mathrm{mg} /$ day for 4 days and SkM 11BHSD1, C/EBP $\beta$ and P1 and P2 promoter region mRNA levels were measured by quantitative RT-PCR. 11ßHSD1 oxoreductase activity was quantified by measuring the conversion of radiolabeled ${ }^{3} \mathrm{H}$-cortisone to cortisol by thin layer chromatography. Analysis of HSD11B1 promoter methylation (P1 and P2) was performed using Sequenom MassARRAY EpiTYPER analysis.

Results: Dexamethasone treatment resulted in a significant increase in $11 \beta H S D 1$ mRNA levels $(P=0.003)$, oxoreductase activity $(P=0.017)$ and C/EBP $\beta$ mRNA $(P=0.015)$, and increased expression of both the P1 $(P=0.008)$ and P2 $(P=0.016)$ promoter regions. The distal P1 promoter region showed a significant reduction in methylation following dexamethasone $(P=0.026)$. There was a significant negative correlation between the change in methylation at this site and the increment in 11BHSD1 oxoreductase activity $(r=-0.62, P=0.014)$.
\end{abstract}

Conclusions: Our findings of reduced methylation in the HSD11B1 P1 promoter in association with increased $11 \beta H S D 1$ oxoreductase activity implicate complex multi-promoter epigenetic mechanisms in the regulation of $11 \beta H S D 1$ levels in SkM.

Keywords: 11ß-Hydroxysteroid dehydrogenase-1, Cortisol, Diabetes, Epigenetics, DNA methylation

\section{Background}

$11 \beta$-Hydroxysteroid dehydrogenase-1 (11ßHSD1) is a bi-directional enzyme, most abundantly expressed in glucocorticoid target tissues such as the liver and adipose [1]. 11ßHSD1 displays predominant oxoreductase activity in intact cells, generating the biologically active

\footnotetext{
* Correspondence: warrick_inder@health.qld.gov.au

'Department of Endocrinology and Diabetes, St Vincent's Hospital, 41 Victoria Parade, Fitzroy, VIC 3065, Australia

${ }^{2}$ Department of Diabetes and Endocrinology, Princess Alexandra Hospital, Ipswich Road, Woolloongabba, QLD 4102, Australia

Full list of author information is available at the end of the article
}

glucocorticoid cortisol from the inactive form, cortisone [2]. In adipose tissue, several studies show increased 11ßHSD1 expression and oxoreductase activity, suggesting that differential elevation of glucocorticoid in this tissue may be involved in the pathogenesis of central obesity [3]. Skeletal muscle $(\mathrm{SkM})$ is a major site of insulin resistance and accounts for the majority of peripheral glucose disposal [4]. We have previously demonstrated that $11 \beta \mathrm{HSD} 1$ is present and biologically active in SkM of both diabetic and nondiabetic subjects [5].

\section{Biomed Central}


Previous in vitro studies in human myoblasts have demonstrated that addition of glucocorticoid upregulates $11 \beta$ HSD1 mRNA levels and activity [6]. This is consistent with other studies in a variety of human tissues including skin fibroblasts [7], amnion fibroblasts [8], and omental adipose stromal cells [9] that implicate glucocorticoids in 11ßHSD1 upregulation. Our own data in people with type 2 diabetes showed that orally administered dexamethasone increases SkM 11ßHSD1 oxoreductase activity [5], but this response was not observed in nondiabetic subjects.

Dexamethasone increases 11ßHSD1 mRNA levels and activity in cultured chorionic trophoblasts, an effect that is blocked by the glucocorticoid receptor antagonist RU486 [10]. Co-localization of 11ßHSD1 and the glucocorticoid receptor was demonstrated [10]. This indicates that the stimulatory effect of glucocorticoids on $11 \beta$ HSD1 is likely to be mediated via the glucocorticoid receptor. Glucocorticoids appear to act in an autocrine manner, stimulating the expression of $11 \beta$ HSD1, which in turn increases conversion of cortisone to active cortisol, a so-called positive feed-forward mechanism [11].

The human genome contains two annotated transcription start sites for the HSD11B1 gene (encoding $11 \beta \mathrm{HSD} 1)$, which are potentially regulated in an independent manner in different tissues (Figure 1). However, mechanisms underlying regulation of this gene remain poorly understood. Several studies have demonstrated the importance of the CCAAT/enhancer-binding protein (C/EBP) transcription factors [11-16] in HSD11B1 expression from the proximal $\mathrm{P} 2$ promoter. In human A549 lung epithelial cells, C/EBP $\beta$ has been shown to mediate the induction of $11 \beta \mathrm{HSD} 1$ by glucocorticoids [13], whereas in human amnion fibroblasts $\mathrm{C} / \mathrm{EBP} \alpha$ rather than $C / E B P \beta$ was involved [11]. However, inhibition of C/EBP is insufficient to completely block glucocorticoid stimulation of $11 \beta$ HSD1 activity, at least in some cells [11].

DNA methylation is an epigenetic process that plays a pivotal role in the regulation of gene expression in both a temporal and spatial manner throughout development [17]. Methylation of DNA in vertebrates occurs almost exclusively in CpG dinucleotides, often clustered in gene promoter regions. Promoter methylation is generally associated with reduced gene activity. Changes in promoter methylation may occur in a dynamic fashion with measured periodicity of as little as 100 minutes [18,19]. The observed induced 11ßHSD1 enzyme activity following glucocorticoid treatment may therefore potentially be associated with a reduction in HSD11B1 promoter methylation. Each of the two annotated HSD11B1 promoters contains $\mathrm{CpG}$ sites, one of which (within the distal P1 promoter) overlaps a conserved glucocorticoid response element (GRE; Figure 1).

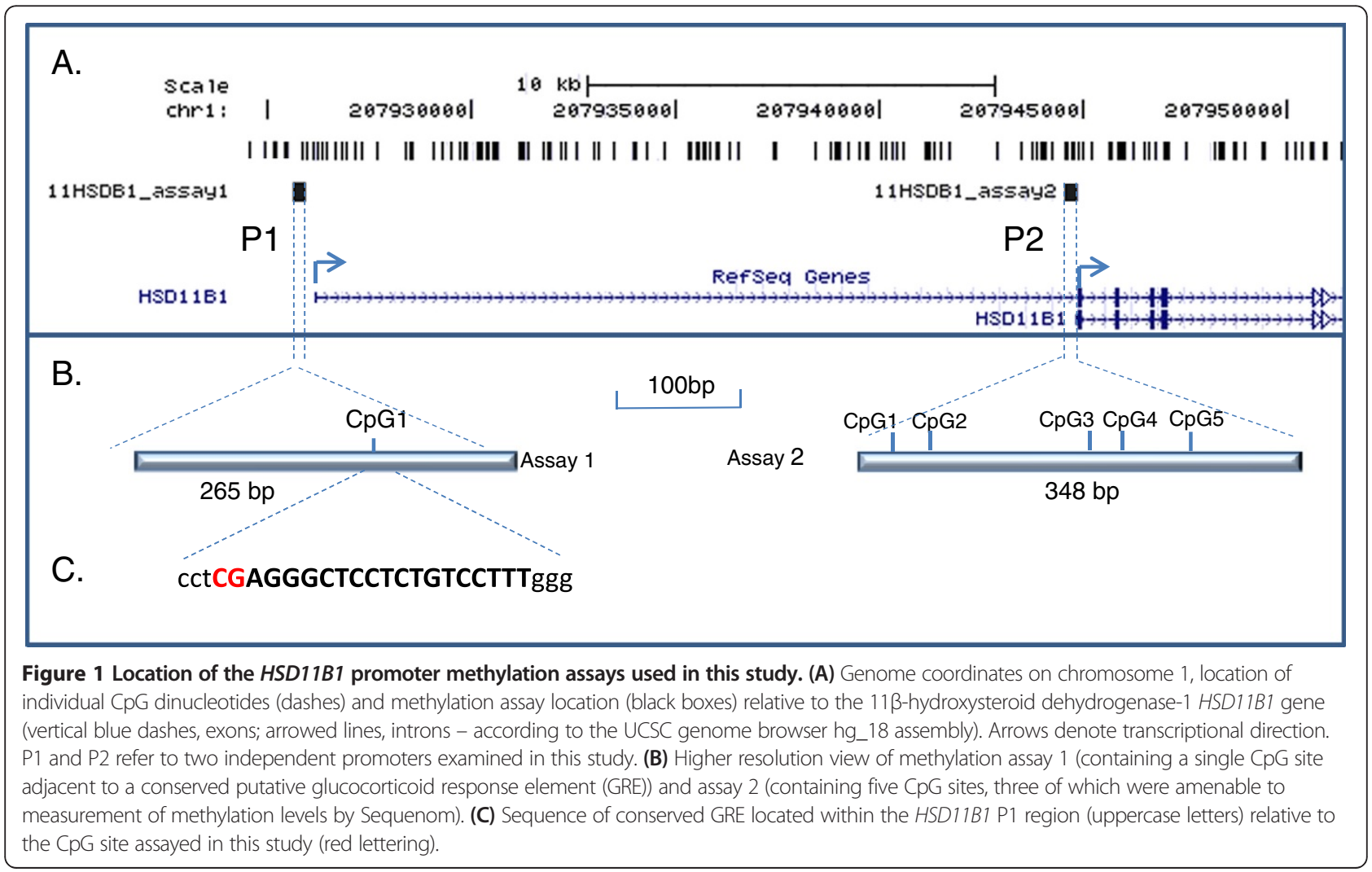


In this study, we tested the hypothesis that the increased $11 \beta$ HSD1 mRNA expression and enzyme activity seen in SkM post dexamethasone treatment is associated with a reduction in DNA methylation at the putative GRE of the HSD11B1 P1 gene promoter in human diabetic subjects.

\section{Results}

The subjects consisted of seven males and eight females with a median age 57 years (range 48 to 66 years). Overall they had moderately well controlled diabetes, with a median (25th to 75 th percentile) HbA1c of $6.9 \%$ (5.8 to $7.8 \%)$. All subjects had some degree of glucocorticoidinduced hyperglycemia and insulin resistance following dexamethasone treatment, with a significant increase in fasting glucose, insulin and HOMA2-IR homeostasis model assessment (Table 1).

Dexamethasone resulted in a significant increase in 11ßHSD1 mRNA $(P=0.003), \mathrm{C} / \mathrm{EBP} \beta$ mRNA $(P=0.015)$ and increased 11ßHSD1 oxoreductase activity $(P=0.017)$ in SkM biopsies, as determined by the Wilcoxon signedrank test, which examines the significance of the median difference between paired values (Table 1 and Figure 2). In the 11 subjects where sufficient cDNA remained for the determination of differential P1 and P2 promoterassociated expression, there was a significant twofold increase in the $\mathrm{P} 1$ promoter derived-transcript $(P=0.008)$ and to a lesser extent the P2 promoter-derived transcript (1.5-fold increase; $P=0.016$ ).

DNA methylation $\beta$-values obtained for HSD11B1 promoters P1 (single CpG site) and P2 (3 CpG sites) are listed in Table 2 . In the case of $\mathrm{P} 2$, the average

Table 1 Patient characteristics before and after dexamethasone $4 \mathrm{mg} /$ day for 4 days

\begin{tabular}{|c|c|c|}
\hline Characteristic & Pre dexamethasone & Post dexamethasone \\
\hline Fasting glucose (mmol/l) & 7.0 (6.1 to 9.8) & $7.6(6.4 \text { to } 12.9)^{a}$ \\
\hline Fasting insulin (mU/l) & 13.1 (9.6 to 15.5$)$ & $15.8(11.4 \text { to } 17.8)^{a}$ \\
\hline HOMA2-IR & $2.0(1.3$ to 2.1$)$ & $2.4(1.6 \text { to } 2.9)^{b}$ \\
\hline $\begin{array}{l}\text { 11ßHSD1 mRNA (relative } \\
\text { expression) }\end{array}$ & $3.06(1.81$ to 4.61$)$ & $3.06(2.70 \text { to } 6.11)^{b}$ \\
\hline $\begin{array}{l}11 \beta \mathrm{HSD} 1 \text { oxoreductase } \\
\text { activity (\% conversion) }\end{array}$ & $11.3(4.7$ to 17.4$)$ & $15.5(11.6 \text { to } 19.3)^{a}$ \\
\hline $\begin{array}{l}\text { C/EBP } \mathrm{mRNA} \text { (relative } \\
\text { expression) }\end{array}$ & 1.37 (0.32 to 2.46) & $2.06(0.85 \text { to } 3.11)^{a}$ \\
\hline $\begin{array}{l}\text { P1 promoter mRNA } \\
\text { (relative expression, } \\
n=11 \text { ) }\end{array}$ & $0.03(0.02$ to 0.04$)$ & $0.06(0.03 \text { to } 0.22)^{b}$ \\
\hline $\begin{array}{l}\mathrm{P} 2 \text { promoter mRNA } \\
\text { (relative expression, } \\
n=11 \text { ) }\end{array}$ & 0.83 (0.63 to 1.13$)$ & $1.40(0.77 \text { to } 1.78)^{a}$ \\
\hline \multicolumn{3}{|c|}{ 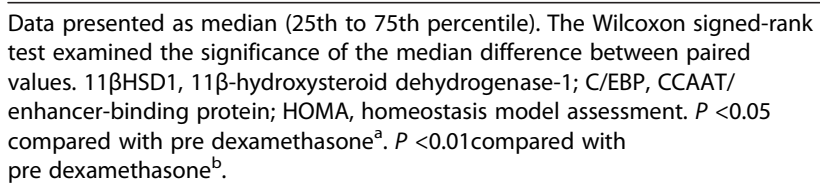 } \\
\hline
\end{tabular}
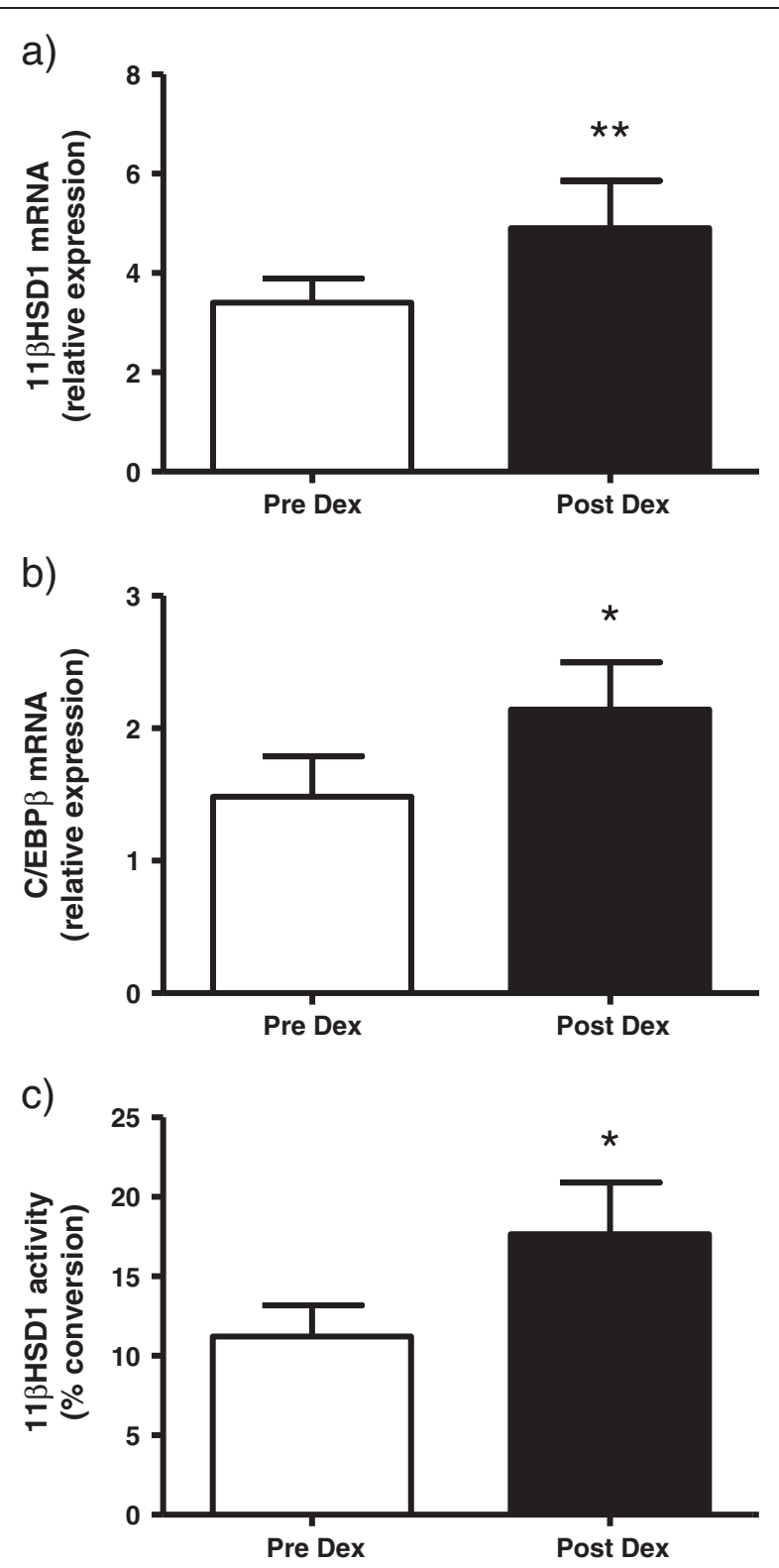

Figure 2 Skeletal muscle $11 \beta$-hydroxysteroid dehydrogenase-1 mRNA, C/EBP $\beta$ and $11 \beta H S D 1$ oxoreductase activity before and after dexamethasone. Mean \pm standard error of skeletal muscle (a) 11ß-hydroxysteroid dehydrogenase-1 (11ßHSD1) mRNA, (b) CCAAT/ enhancer-binding protein (C/EBP $\beta$ ) and (c) $11 \beta H S D 1$ oxoreductase activity before ( $\square$ ) and after ( $\square$ ) dexamethasone $4 \mathrm{mg} /$ day for 4 days in 15 subjects with type 2 diabetes. ${ }^{*} P<0.05$, ${ }^{*} P<0.01$ by Wilcoxon signed-rank test.

methylation level was calculated from the three analyzable $\mathrm{CpG}$ sites. The distal P1 region, containing a putative GRE, showed a significant reduction in median methylation level, from $32 \%$ to $30 \%$, following dexamethasone treatment $(P=0.026)$. Furthermore, there was a significant negative correlation via the Spearman test between the change in methylation at this site and 
Table 2 DNA methylation scores before and after dexamethasone $4 \mathrm{mg} /$ day for 4 days

\begin{tabular}{lccc}
\hline Methylation site & $\begin{array}{c}\text { Before } \\
\text { dexamethasone } \\
\text { (\%) }\end{array}$ & $\begin{array}{c}\text { After } \\
\text { dexamethasone } \\
\text { (\%) }\end{array}$ & P value \\
\hline P1 promoter CpG & 32 (29 to 35) & 30 (28 to 33) & 0.026 \\
\hline P2 promoter (CpG mean) & 42 (37 to 43) & 38 (36 to 41) & 0.093 \\
\hline (P2_CpG 2) & 22 (16 to 24) & $18(17$ to 22) & 0.072 \\
\hline (P2_CpG 3) & 41 (33 to 44) & 37 (35 to 42) & 0.409 \\
\hline (P2_CpG 4) & 63 (58 to 66) & $59(56$ to 62) & 0.065 \\
\hline
\end{tabular}

Data presented as median (25th to 75 th percentile). Methylation scores (approximating \% of alleles with cytosine methylation at specific CpG sites within a tissue sample) were obtained from the Mass Spec output using EpiTYPER v1.0.5 software (Sequenom Inc, San Diego, CA, USA). Only a single $\mathrm{CpG}$ site was present in the P1 promoter region tested, whereas three sites in close proximity were assessed in P2.

the increment in 11ßHSD1 oxoreductase activity (Figure $3, r=-0.62, P=0.014$ ). In the $\mathrm{P} 2$ promoter region, there was no significant change in total DNA methylation across the three sites tested $(P=0.093)$, although a consistent decrease in median methylation was observed at each site post dexamethasone treatment. There was not a significant correlation between the change in $11 \beta H S D 1$ mRNA and P1 methylation.

\section{Discussion}

We have previously demonstrated that oral dexamethasone administered at a dose of $4 \mathrm{mg} /$ day for 4 days increases 11ßHSD1 oxoreductase activity in SkM of subjects with type 2 diabetes but not nondiabetic subjects [5]. We have now extended these findings by examining the association of the DNA methylation level in two annotated promoter regions with gene expression levels and enzyme activity in the diabetic group, which is subject to upregulation by dexamethasone. Evidence, primarily from accumulated expressed sequence tag

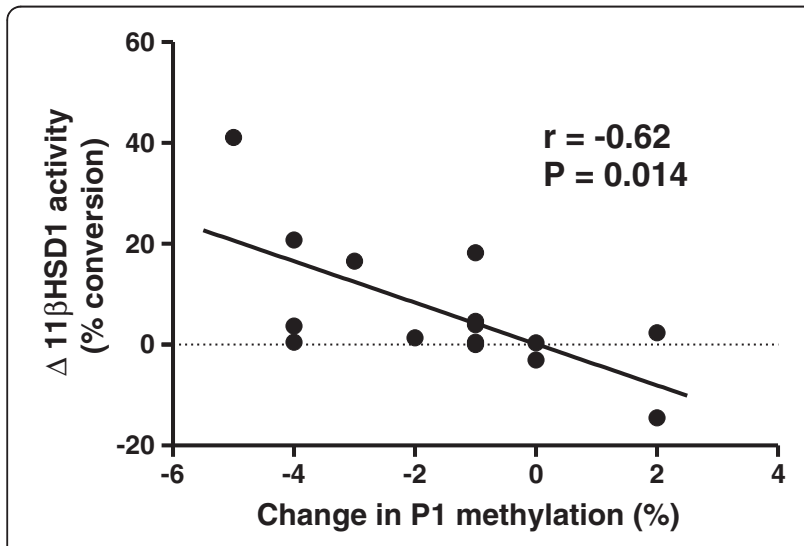

Figure 3 Correlation between change in $\mathrm{P} 1$ promoter methylation and $11 \beta$-hydroxysteroid dehydrogenase- 1 oxoreductase activity in skeletal muscle. $r=-0.62, P=0.014$. data, suggests that the HSD11B1 has two independent transcription start sites and associated promoters, designated P1 [14] and P2. In the mouse, the P1 promoter predominates in the lung and is independent of $\mathrm{C} / \mathrm{EBP} \alpha$, while the $\mathrm{P} 2$ promoter predominates in the liver, adipose tissue and brain [14]. At present the predominant transcriptional start site in SkM remains unclear, although our data confirm that both transcripts are present. The P1 promoter region is CpG poor but contains a conserved putative GRE upstream of the transcriptional start site.

In this study we demonstrated that the dexamethasoneinduced increase in overall 11ßHSD1 mRNA, derived from both P1 and P2 promoters, and enzyme activity is associated with a significantly reduced level of DNA methylation at the putative GRE-associated CpG site in HSD11B1 P1. Further, the extent of methylation reduction correlates significantly with the subsequent increase in 11ßHSD1 enzyme activity. While a statistical association does not prove causality, the findings suggest that HSD11B1 expression may be subject to dynamic epigenetic modulation in response to glucocorticoid status. This is further supported by the finding of significant upregulation of the P1 promoter-derived transcript following dexamethasone treatment. The absolute changes in methylation were small, but so were the changes in SkM 11ßHSD1 activity in many of the subjects. Indeed in two subjects where a small decrease in 11ßHSD1 activity was observed, P1 promoter methylation was increased or unchanged. Such a modest effect size is in accordance with other emerging studies in complex disease that routinely report small changes in DNA methylation in a case-control setting. As an example, Rakyan and colleagues identify small diseaseassociated methylation differences of 1.3 to $6.6 \%$, which compare well with other multiple referenced studies in complex disease and our data [20]. They point out that this could be 'the norm for complex disease associated epigenetic variation' [20].

While methylation of a single CpG site was analyzed in the $\mathrm{P} 1$ promoter region, analysis of methylation of the CpG sites within the P2 region did not produce statistically significant changes following dexamethasone. The dose of dexamethasone utilized in this study is within the range used clinically, and completely suppresses the hypothalamic-pituitary adrenal axis, leading to the near absence of circulating cortisol. Dexamethasone induced insulin resistance in both diabetic and nondiabetic subjects and resulted in an elevation in fasting glucose, insulin and HOMA2-IR homeostasis model assessment in the current study.

P2-associated transcription of HSD11B1 via the C/EBP transcription factors has previously been described [11]. The $11 \beta$ HSD1 P2 promoter contains $10 \mathrm{C} / \mathrm{EBP}$ binding 
sites. The precise role of the different C/EBPs in the regulation of $11 \beta \mathrm{HSD} 1$ appears to be tissue specific. In HepG2 (hepatoma) cells, C/EBP $\alpha$ is the predominant regulator of $11 \beta \mathrm{HSD} 1$ expression, while $\mathrm{C} / \mathrm{EBP} \beta$ is only a weak activator in the absence of C/EBP $\alpha$ [15]. Both $\mathrm{C} / \mathrm{EBP} \alpha$ and $\mathrm{C} / \mathrm{EBP} \beta$ are required for basal transcriptional activity of $11 \beta \mathrm{HSD} 1$ in the mouse pre-adipocyte cell line 3T3-L1 [12]. Induction of C/EBP $\alpha$ shows a greater increase in basal 11ßHSD1 expression, while $\mathrm{C} / \mathrm{EBP} \beta$ is the key factor mediating the increase in $11 \beta H S D 1$ in response to cyclic AMP stimulation in these cells [12]. In human A549 lung epithelial cells, the stimulatory effect of dexamethasone on 11ßHSD1 activity appears to be mediated by two mechanisms. Firstly, 11ßHSD1 activity is dependent on the glucocorticoid receptor, since the co-administration of the glucocorticoid receptor antagonist RU486 blocks it; and secondly, the stimulatory effect of dexamethasone is indirect requiring new protein synthesis, since the glucocorticoid upregulation is also blocked by the protein synthesis inhibitor cycloheximide [13]. While a GRE lies between two key C/EBP binding sites in the P2 promoter, mutation of this GRE region did not appear to affect dexamethasone responsiveness [13]. C/EBP $\beta$, but not $\mathrm{C} / \mathrm{EBP} \alpha$ or $\mathrm{C} / \mathrm{EBP} \delta$, is a crucial mediator of the increased $11 \beta \mathrm{HSD} 1$ expression and activity following dexamethasone in A549 cells [13]. In contrast, in the human adipocyte cell line PAZ6, C/EBP $\alpha$ but not C/EBP $\beta$ or C/EBP $\delta$ was induced by dexamethasone [21].

We have shown here that humans administered exogenous dexamethasone exhibit a significant rise in SkM $\mathrm{C} / \mathrm{EBP} \beta$ mRNA levels consistent with the findings of Yang and colleagues [16]. The extent of the increase in $\mathrm{C} / \mathrm{EBP} \beta$ and $11 \beta \mathrm{HSD} 1$ in SkM was considerably less than observed by Sai and colleagues, who showed a 12 -fold increase in 11ßHSD1 mRNA levels in response to a threefold to fourfold increase in C/EBP $\beta$ in A549 lung epithelial cells [13]. Since our data demonstrated an increase in expression of both P1 and P2 promoters, we suggest that there may be a dual mechanism of dexamethasone-induced activation of SkM 11ßHSD1 activity; via demethylation of the P1 promoter and through C/EBP $\beta$ stimulation of the P2 promoter.

In SkM, the precise mechanism(s) involved in glucocorticoid-induced activation of $11 \beta \mathrm{HSD}$ remain to be characterized. Which promoter (P1 or P2) is used in muscle to transcribe the HSD11B1 gene in response to glucocorticoid was previously not known, although we have now shown that both transcripts are clearly detectable by specific RT-PCR. In vitro reporter experiments aimed at demonstrating functionality of the putative P1-associated GRE in appropriate cell models are required to confirm the functionality of this region in the observed glucocorticoid response. The P2-associated
CpG sites are not associated with a putative GRE, suggesting that a reduction in methylation at the P2 promoter of HSD11B1 is not associated with the increased SkM 11ßHSD1 activity following dexamethasone administration.

The enzyme 11ßHSD type 2 (11ßHSD2), which converts cortisol to cortisone, is highly expressed in mineralocorticoid target tissues such as the kidney and colon, but is expressed at low levels in SkM [5]. There is evidence that $11 \beta \mathrm{HSD} 2$ is subject to epigenetic regulation, both at the level of DNA methylation but also of the histone modification profile [22]. Human subjects who developed hypertension when treated with prednisone had increased 11ßHSD2 promoter methylation in peripheral blood mononuclear cells [23]. Our previous work demonstrated that SkM 11ßHSD2 expression and activity was downregulated in the type 2 diabetic subjects [5]. This downregulation may thus possibly be associated with increased methylation of the 11ßHSD2 promoter, but this was not the focus of the present study.

Methylation of DNA is a well-described mechanism of epigenetic modulation of gene expression. DNA methylation had been assumed not to be as dynamic as other epigenetic processes. However, recent studies have demonstrated that highly dynamic DNA methylation changes can occur even during the relatively short period of a single cell cycle in a number of human genes $[13,19]$. Other studies have examined epigenetic mechanisms in metabolic pathways in SkM of human subjects. NonCpG methylation of the peroxisome proliferatoractivated receptor $\gamma$ coactivator-1 $\alpha$ (PGC-1 $\alpha)$ gene in myotubes has been associated with reductions in mitochondrial density in subjects with type 2 diabetes [24]. Furthermore, elevated DNA methylation of SkM PGC- $1 \alpha$ is observed in normal birth weight nondiabetic subjects overfed a high-fat diet [25]. Our findings support the involvement of DNA methylation at the conserved putative GRE in the P1 11ßHSD1 promoter in the regulation of glucocorticoid-induced HSD11B1 gene activation in human SkM. Specifically, we find that the extent of the reduction in methylation of this GRE following dexamethasone correlates with the subsequent increment in SkM 11ßHSD1 oxoreductase activity. While the putative GRE in the P1 11ßHSD1 promoter may have a lesser role compared with C/EBPstimulated P2 promoter activation in many tissues, our results suggest that even relatively small changes in methylation may influence the extent of the increment in SkM 11ßHSD1 activity. However, this does not preclude the existence of a parallel response involving $\mathrm{C} / \mathrm{EBP} \beta$ action at the P2 promoter. Further functional studies are required to determine the relative contribution of these promoter regions and regulatory 
mechanisms to the overall regulation of the HSD11B1 gene in SkM.

\section{Conclusion}

This study has found a reduction in methylation of the putative GRE within the P1 promoter of HSD11B1 that correlates with gene expression and the increase in $11 \beta H S D 1$ oxoreductase activity in SkM following dexamethasone treatment. This observation implicates dynamic epigenetic remodeling in the regulation of glucocorticoid action via $11 \beta H S D 1$.

\section{Methods}

The experimental protocol was approved by the institutional Human Research Ethics Committee. Fifteen volunteers with type 2 diabetes gave written informed consent for participation. The subjects were treated by diet alone $(n=4)$ or with oral hypoglycemic agents (metformin alone, $n=2$; a sulphonylurea alone, $n=2$; or both, $n=7$ ). No patient was using insulin or thiazolidinediones. Exclusion criteria included poorly controlled hypertension (systolic blood pressure $\geq 160 \mathrm{mmHg}$ and/or diastolic blood pressure $\geq 90 \mathrm{mmHg}$ ), a history of liver or renal disease, and evidence of unstable angina or peripheral vascular disease. Data from 12 of these subjects were included in our previous study examining the effect of oral dexamethasone on 11ßHSD1 and 11ßHSD2 in diabetic and nondiabetic subjects [5]. Nondiabetic subjects were not included in this study because we had previously shown that the induction of $11 \beta \mathrm{HSD} 1$ oxoreductase activity did not occur in this group.

\section{Experimental design}

After an overnight 10-hour fast, subjects had venous blood samples drawn between 08:00 and 08:30 hours for glucose, insulin and HbA1c. Body weight, body mass index and waist-to-hip ratio were determined for each subject.

After sedation with intravenous midazolam and administration of local anesthetic, biopsy of the vastus lateralis was performed using a $5 \mathrm{~mm}$ Bergstrom needle as previously described [26]. Fresh muscle was rapidly dissected of visible adipose and connective tissue and placed in DMEM for enzyme activity studies. Additional SkM from the same biopsy was snap-frozen in liquid nitrogen for mRNA analysis and epigenetic studies, with storage at $-70^{\circ} \mathrm{C}$. Within 28 days, subjects were administered oral dexamethasone (4 mg daily) for 4 days before repeat blood sampling and muscle biopsy. The subjects were clear that the dexamethasone was being administered for experimental rather than therapeutic purposes, and warned that dexamethasone would increase their blood glucose levels. They monitored their capillary blood glucose levels at least twice daily during dexamethasone therapy, and were contacted by an investigator on a daily basis.

\section{Laboratory assays}

Plasma glucose was analyzed by a glucose oxidase method employing a YSI 1500 Sidekick analyzer (Yellow Springs Instrument Company, Yellow Springs, OH, USA), with coefficient of variation $2.4 \%$. Plasma insulin was measured with a radioimmunoassay, with $<1 \%$ cross-reactivity to proinsulin and sensitivity of $0.5 \mathrm{mU} / \mathrm{l}$. Insulin antibodies were not present in any sample. HbA1c was measured by a high-performance liquid chromatography assay. Homeostasis model assessment was calculated using the computer program of Levy and colleagues [27].

\section{Quantitative real-time RT-PCR}

Relative SkM mRNA levels for $11 \beta \mathrm{HSD} 1$ and C/EBP $\beta$ were determined using quantitative real-time RT-PCR (Taqman ${ }^{\circledR}$, Applied Biosystems, Foster City, CA, USA ). Singleplex reactions were performed using 11ßHSD1 specific primers with normalization to the endogenous control human 18s rRNA (Applied Biosystems, Foster City, CA, USA) as in our previous studies $[5,26]$. The RT-PCR product overlapped exons 2 and 3 of the HSD11B1 gene. Relative 11ßHSD1 mRNA levels were calculated using the $\Delta \Delta C_{\mathrm{T}}$ methodology (using the formula $2^{\Delta \Delta C T}$ ). Human $C / E B P \beta$ expression levels were assessed using a specific pre-validated assay obtained from Applied Biosystems. Total RNA from commercially obtained human SkM (BD Biosciences, Palo Alto, CA, USA) was reverse transcribed to cDNA and was used as the calibrator in all experiments. The $\Delta \mathrm{C}_{\mathrm{T}}$ value for each subject was expressed as a ratio with the $\Delta C_{\mathrm{T}}$ measured from the commercially obtained SkM cDNA. Sufficient cDNA allowed quantification of the P1 and P2 promoter regions of $H S D 11 B 1$ before and after dexamethasone in $11 / 15$ subjects.

\section{$11 \beta$-Hydroxysteroid dehydrogenase-1 enzyme activity}

Oxoreductase enzyme activity of 11ßHSD1 was determined in dispersed fresh SkM after overnight incubation, by measuring the conversion of radiolabeled ${ }^{3} \mathrm{H}$-cortisone to cortisol by thin layer chromatography, as described in our previous studies [5,26].

\section{Genomic DNA extraction}

Muscle samples were incubated at $50^{\circ} \mathrm{C}$ overnight in DNA extraction buffer $(100 \mathrm{mM} \mathrm{NaCl}, 10 \mathrm{mM}$ Tris- $\mathrm{HCl} \mathrm{pH} 8$, $25 \mathrm{mM}$ ethylenediamine tetraacetic acid, $0.5 \%$ SDS) with $200 \mu \mathrm{g} / \mathrm{ml}$ Proteinase K. DNA was then isolated by two rounds of phenol-chloroform extraction, followed by RNAse A treatment, precipitation in ethanol containing $10 \%$ sodium acetate $(3 \mathrm{M}, \mathrm{pH} 5.2)$, with resuspension in 
$100 \mu \mathrm{l}$ nuclease-free water (Ambion, Austin, TX, USA). DNA was quantitated and quality assessed by spectrophotometry on a Nanodrop (ThermoFisher Scientific, Waltham, MA, USA), and checked for integrity by gel electrophoresis, with subsequent storage at $-20^{\circ} \mathrm{C}$.

\section{HSD11B1 promoter methylation}

Figure 1 outlines the location of the HSD11B1 promoter methylation assays used in this study. Sequenom MassARRAY EpiTYPING was carried out as previously described $[28,29]$. DNA samples were processed using the Methyl Easy bisulphite modification kit (Human Genetic Signatures, North Ryde, NSW, Australia) according to the manufacturer's instructions. Amplification was performed on converted genomic DNA using primers directed to modified DNA: 11HSDB1_F1, 5'aggaagagagTGGTGAAAAGGGAAAATTTGTTT and 11HSDB1_R1， 5'-cagtaatacgactcactatagggagaaggctCCT ACAAAAACAACTCCAAAAAA for distal promoter 1 (P1); and 11HSDB1_F2, 5'-aggaagagagTTTTTGAA AGATTATTGATTTTTGG and 11HSDB1_R2, $5^{\prime}$-cagt aatacgactcactatagggagaaggctTCCTATAAAACACACAAAA AAAACC for proximal promoter 2 (P2) (lowercase denotes sequence tags added to facilitate downstream EpiTYPER analysis). EpiTYPER analysis produces a methylation $\beta$-value (approximately equivalent to total percentage methylation). All PCR amplifications and subsequent MassArray runs were performed in triplicate for calculation of mean methylation $\beta$-values at each analyzable CpG site.

\section{Statistical analysis}

The raw data failed to satisfy parametric assumptions, and therefore nonparametric tests were used in the analysis. Tabulated data are expressed as the median (25th to 75 th percentile), while Figure 2 presents the mean \pm standard error of the mean. The mRNA expression, $11 \beta H S D 1$ enzyme activity and changes in promoter DNA methylation score in response to dexamethasone were analyzed by the Wilcoxon signed-rank test, which examines the significance of the median difference between paired values. The correlation between the incremental response of $11 \beta \mathrm{HSD} 1$ activity and changes in mean promoter methylation was analyzed by the Spearman correlation coefficient. The level of statistical significance was set at $P<0.05$.

\section{Abbreviations \\ 11ßHSD1: 11ß-hydroxysteroid dehydrogenase-1; C/EBP: CCAAT/enhancer- binding protein transcription factors; DMEM: Dulbecco's Modified Eagle Medium; GRE: Glucocorticoid response element; PCR: Polymerase chain reaction; $\mathrm{RT}$ : Reverse transcriptase; SkM: Skeletal muscle.}

\section{Competing interests}

The authors declare that they have no competing interests.

\section{Authors' contributions}

WJI performed the statistical analysis and wrote the initial draft of the manuscript. VRO performed the biochemical, molecular and epigenetic analyses and assisted in editing the manuscript. CJ recruited the participants, performed the muscle biopsies and assisted in editing the manuscript. RS provided the intellectual expertise, coordinated epigenetic studies and assisted in manuscript preparation. All authors read and approved the final manuscript.

\section{Acknowledgements}

Dr Christina Jang was awarded the Novartis Oncology Endocrinology Fellowship from the Royal Australasian College of Physicians in 2009. This study was funded in part by a grant from the Diabetes Australia Research Trust (DART). Special thanks to Nick Wong, Boris Novakovic and HK Ng for their help with Sequenom MassARRAY Epityping

\section{Author details}

${ }^{1}$ Department of Endocrinology and Diabetes, St Vincent's Hospital, 41 Victoria Parade, Fitzroy, VIC 3065, Australia. ${ }^{2}$ Department of Diabetes and Endocrinology, Princess Alexandra Hospital, Ipswich Road, Woolloongabba, QLD 4102, Australia. ${ }^{3}$ School of Medicine, University of Queensland, 288 Herston Road, Herston, QLD 4006, Australia. ${ }^{4}$ Centres for Health Research, Princess Alexandra Hospital, Ipswich Road, Woolloongabba, QLD 4102, Australia. ${ }^{5}$ Developmental Epigenetics, Murdoch Children's Research Institute and Department of Paediatrics, University of Melbourne, Royal Children's Hospital, Flemington Road, Parkville, VIC 3052, Australia.

Received: 16 August 2012 Accepted: 12 November 2012 Published: 17 December 2012

\section{References}

1. Tomlinson JW, Walker EA, Bujalska IJ, Draper N, Lavery GG, Cooper MS, Hewison M, Stewart PM: 11ß-Hydroxysteroid dehydrogenase type 1: a tissue-specific regulator of glucocorticoid response. Endocr Rev 2004, 25:831-866.

2. Stewart PM: $11 \beta$-Hydroxysteroid dehydrogenase: implications for clinical medicine. Clin Endocrinol (Oxf) 1996, 44:493-499.

3. Draper N, Stewart PM: 11ß-Hydroxysteroid dehydrogenase and the prereceptor regulation of corticosteroid hormone action. J Endocrinol 2005 186:251-271.

4. DeFronzo RA, Gunnarsson R, Bjorkman O, Olsson M, Wahren J: Effects of insulin on peripheral and splanchnic glucose metabolism in noninsulindependent (type II) diabetes mellitus. J Clin Invest 1985, 76:149-155.

5. Jang C, Obeyesekere VR, Dilley RJ, Krozowski Z, Inder WJ, Alford FP: Altered activity of $11 \beta$-hydroxysteroid dehydrogenase types 1 and 2 in skeletal muscle confers metabolic protection in subjects with type 2 diabetes. J Clin Endocrinol Metab 2007, 92:3314-3320.

6. Whorwood CB, Donovan SJ, Flanagan D, Phillips DI, Byrne CD: Increased glucocorticoid receptor expression in human skeletal muscle cells may contribute to the pathogenesis of the metabolic syndrome. Diabetes 2002, 51:1066-1075.

7. Hammami MM, Siiteri PK: Regulation of $11 \beta$-hydroxysteroid dehydrogenase activity in human skin fibroblasts: enzymatic modulation of glucocorticoid action. J Clin Endocrinol Metab 1991, 73:326-334.

8. Sun K, Myatt L: Enhancement of glucocorticoid-induced 11ß-hydroxysteroid dehydrogenase type 1 expression by proinflammatory cytokines in cultured human amnion fibroblasts. Endocrinology 2003, 144:5568-5577.

9. Bujalska IJ, Kumar S, Stewart PM: Does central obesity reflect 'Cushing's disease of the omentum'? Lancet 1997, 349:1210-1213.

10. Sun K, He P, Yang K: Intracrine induction of $11 \beta$-hydroxysteroid dehydrogenase type 1 expression by glucocorticoid potentiates prostaglandin production in the human chorionic trophoblast. Biol Reprod 2002, 67:1450-1455.

11. Yang Z, Guo C, Zhu P, Li W, Myatt L, Sun K: Role of glucocorticoid receptor and CCAAT/enhancer-binding protein alpha in the feed-forward induction of $11 \beta$-hydroxysteroid dehydrogenase type 1 expression by cortisol in human amnion fibroblasts. J Endocrinol 2007, 195:241-253.

12. Gout J, Tirard J, Thevenon C, Riou JP, Begeot M, Naville D: CCAAT/enhancerbinding proteins (C/EBPs) regulate the basal and CAMP-induced transcription of the human $11 \beta$-hydroxysteroid dehydrogenase encoding gene in adipose cells. Biochimie 2006, 88:1115-1124. 
13. Sai S, Esteves $C L$, Kelly V, Michailidou Z, Anderson K, Coll AP, Nakagawa $Y$, Ohzeki T, Seckl JR, Chapman KE: Glucocorticoid regulation of the promoter of $11 \beta$-hydroxysteroid dehydrogenase type 1 is indirect and requires CCAAT/enhancer-binding protein-beta. Mol Endocrinol 2008, 22:2049-2060

14. Bruley C, Lyons V, Worsley AG, Wilde MD, Darlington GD, Morton NM, Seckl JR, Chapman KE: A novel promoter for the $11 \beta$-hydroxysteroid dehydrogenase type 1 gene is active in lung and is C/EBPa independent. Endocrinology 2006, 147:2879-2885.

15. Williams LJ, Lyons V, MacLeod I, Rajan V, Darlington GJ, Poli V, Seckl JR, Chapman KE: C/EBP regulates hepatic transcription of $11 \beta$ hydroxysteroid dehydrogenase type 1 . A novel mechanism for cross-talk between the C/EBP and glucocorticoid signaling pathways. J Biol Chem 2000, 275:30232-30239.

16. Yang H, Mammen J, Wei W, Menconi M, Evenson A, Fareed M, Petkova V, Hasselgren PO: Expression and activity of C/EBPbeta and delta are upregulated by dexamethasone in skeletal muscle. J Cell Physiol 2005, 204:219-226.

17. Foley DL, Craig JM, Morley R, Olsson CA, Dwyer T, Smith K, Saffery R: Prospects for epigenetic epidemiology. Am J Epidemio/ 2009, 169:389-400.

18. Kangaspeska S, Stride B, Metivier R, Polycarpou-Schwarz M, Ibberson D, Carmouche RP, Benes V, Gannon F, Reid G: Transient cyclical methylation of promoter DNA. Nature 2008, 452:112-115.

19. Metivier R, Gallais R, Tiffoche C, Le Peron C, Jurkowska RZ, Carmouche RP, Ibberson D, Barath P, Demay F, Reid G, Benes V, Jeltsch A, Gannon F, Salbert G: Cyclical DNA methylation of a transcriptionally active promoter. Nature 2008, 452:45-50.

20. Rakyan VK, Beyan H, Down TA, Hawa Ml, Maslau S, Aden D, Daunay A, Busato F, Mein CA, Manfras B, Dias KR, Bell CG, Tost J, Boehm BO, Beck S, Leslie RD: Identification of type 1 diabetes-associated DNA methylation variable positions that precede disease diagnosis. PLoS Genet 2011, 7: e1002300.

21. Zilberfarb V, Siquier K, Strosberg AD, Issad T: Effect of dexamethasone on adipocyte differentiation markers and tumour necrosis factor-alpha expression in human PAZ6 cells. Diabetologia 2001, 44:377-386.

22. Alikhani-Koopaei R, Fouladkou F, Frey FJ, Frey BM: Epigenetic regulation of 11ß-hydroxysteroid dehydrogenase type 2 expression. J Clin Invest 2004, 114:1146-1157.

23. Friso S, Pizzolo F, Choi SW, Guarini P, Castagna A, Ravagnani V, Carletto A, Pattini P, Corrocher R, Olivieri O: Epigenetic control of $11 \beta$-hydroxysteroid dehydrogenase 2 gene promoter is related to human hypertension. Atherosclerosis 2008, 199:323-327.

24. Barres R, Osler ME, Yan J, Rune A, Fritz T, Caidahl K, Krook A, Zierath JR: Non-CpG methylation of the PGC-1.alpha; promoter through DNMT3B controls mitochondrial density. Cell Metab 2009, 10:189-198.

25. Brons C, Jacobsen S, Nilsson E, Ronn T, Jensen CB, Storgaard H, Poulsen P, Groop L, Ling C, Astrup A, Vaag A: Deoxyribonucleic acid methylation and gene expression of PPARGC1A in human muscle is influenced by highfat overfeeding in a birth-weight-dependent manner. J Clin Endocrinol Metab 2010, 95:3048-3056.

26. Jang C, Obeyesekere VR, Dilley RJ, Alford FP, Inder WJ: 11Beta hydroxysteroid dehydrogenase type 1 is expressed and is biologically active in human skeletal muscle. Clin Endocrinol (Oxf) 2006, 65:800-805.

27. Levy JC, Matthews DR, Hermans MP: Correct homeostasis model assessment (HOMA) evaluation uses the computer program. Diabetes Care 1998, 21:2191-2192.

28. Ehrich M, Nelson MR, Stanssens P, Zabeau M, Liloglou T, Xinarianos G, Cantor CR, Field JK, van den Boom D: Quantitative high-throughput analysis of DNA methylation patterns by base-specific cleavage and mass spectrometry. Proc Natl Acad Sci U S A 2005, 102:15785-15790.

29. Wong N, Morley R, Saffery R, Craig J: Archived Guthrie blood spots as a novel source for quantitative DNA methylation analysis. Biotechniques 2008, 45:423-424. 426, 428, passim.

doi:10.1186/1868-7083-4-24

Cite this article as: Inder et al:: Evidence for transcript-specific epigenetic regulation of glucocorticoid-stimulated skeletal muscle $11 \beta$ hydroxysteroid dehydrogenase-1 activity in type 2 diabetes. Clinical Epigenetics 2012 4:24.

\section{Submit your next manuscript to BioMed Central and take full advantage of:}

- Convenient online submission

- Thorough peer review

- No space constraints or color figure charges

- Immediate publication on acceptance

- Inclusion in PubMed, CAS, Scopus and Google Scholar

- Research which is freely available for redistribution 